\title{
DISTRIBUIÇÃO DE FORAMINÍFEROS E TECAMEBAS NO COMPLEXO ESTUARINO DA BAÍA DE PARANAGUÁ-PR
}

\author{
KÁTIA SIMONE JAWORSKI ${ }^{*}$
}

\author{
DISSERTAÇÃO DE MESTRADO - Programa de Pós-Graduação em Geologia - UFPR \\ DATA DE DEFESA: 13 ago. 2001
}

\begin{abstract}
O principal objetivo deste trabalho foi compreender a distribuição dos foraminíferos bentônicos e tecamebas no verão e inverno, no complexo estuarino da Baía de Paranaguá-PR. Cento e doze amostras foram coletadas nas campanhas de verão e inverno de 1999. Dados de parâmetros hidrográficos (temperatura e salinidade), batimetria e parâmetros sedimentológicos (granulometria, matéria orgânica e carbonato de cálcio) foram obtidos para correlação com as associações microfaunísticas. Na área de estudo, foram observadas nas campanhas de verão e de inverno, as subordens Rotaliina, Textulariina e Miliolina de foraminíferos. No verão, predominaram os foraminíferos rotalííneos, provavelmente em razão da estratificação da coluna d'água pelo grande aporte de água doce. No inverno, devido ao acentuado declínio dos rotaliíneos em função do menor alcance da cunha salina e menos estratificações em relação ao verão, predominaram os foraminíferos textulariíneos. A freqüência de tecamebas foi pequena
\end{abstract}

no verão, ao passo que no inverno foram abundantes e associadas aos foraminíferos aglutinantes. Os foraminíferos miliolíneos foram bioindicadores de ambientes bem oxigenados devido à energia do meio. Outro bioindicador importante foi a espécie Pararotalia cananeiaensis, indicando no estuário ambientes com influência marinha. Por meio da análise de agrupamento, duas grandes associações de foraminíferos e tecamebas foram definidas para a campanha de verão: I - Pararotalia cananeiaensis/Bolivina striatula e II - Elphidium sp./ Caronia exilis. Para a campanha de inverno, foram definidas quatro associações distintas: I - Pararotalia cananeiaensis/Pseudononion atlanticum, II Cribroelphidium poyeanum/Ammonia tepida, III - Difflugia oblonga/Deuterammina ochracea/Lagenodifflugia vas e IV - Caronia exilis / Ammobaculites exiguus. A distribuição das associações de foraminíferos e tecamebas no estuário é condicionada, tanto no verão como no inverno, pela profundidade e salinidade.

*E-mail: katia_simonej@hotmail.com 